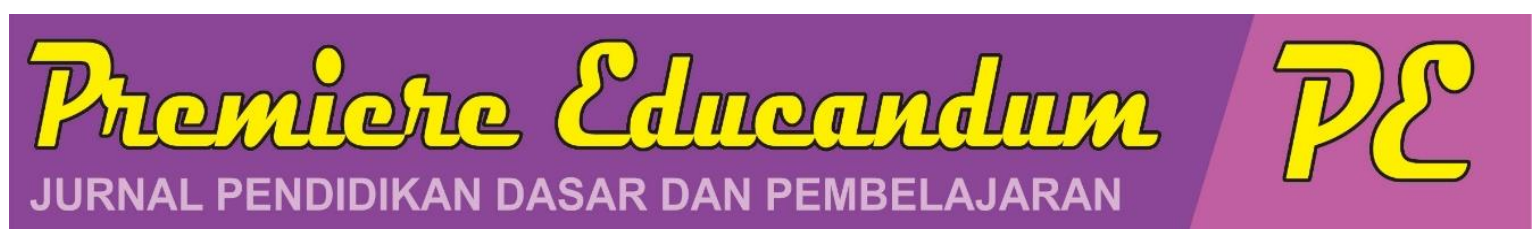

Premiere Educandum: Jurnal Pendidikan Dasar dan Pembelajaran

Volume 8(1) 161 - 172 Desember 2018

Copyright (C2018 Universitas PGRI Madiun

ISSN: 2088-5350 (Print) / ISSN: 2528-5173 (Online)

Available at: http://e-journal.unipma.ac.id/index.php/PE

Doi: $10.25273 /$ pe.v8i2.3158

\title{
Keefektifan lembar kerja siswa tematik berbasis local wisdom terhadap karakter kerja sama siswa kelas 1 SD
}

\author{
Amaliyah Ulfah ${ }^{1}$, Siska Trianiningsih ${ }^{2}$ \\ ${ }^{1}$ FKIP, Universitas Ahmad Dahlan \\ email: amaliyah.ulfah@pgsd.ac.id \\ ${ }^{2}$ FKIP, Universitas Ahmad Dahlan \\ email: trianisiska24@gmail.com
}

\begin{abstract}
This study aims at investigating the effectiveness of students' worksheet based on local wisdom on the cooperative character of first grade primary students. This is a quasi-experiment research with pretestposttest control group design. The population in this research was all first grade students of SD Muhammadiyah Noyokerten. This research consisted of control group and experimental group. The control group was class 1B with the total number of 24 students, and the experimental group was the students of 1A which consisted of 23 students. Data collection techniques used were observation and interview. Independent Sample T-Test was used to measure the effectiveness of students' worksheet based on local wisdom of cooperative character. The results showed that the implementation of students' worksheet based on local wisdom was effective on cooperative character of class 1 students. This is based on the results of hypothesis testing that shows the value of sig 0.006 which means the value $<0.05$ then $\mathrm{H} 1$ accepted. On the other hand, the implementation of students' worksheet based on local wisdom was proven effective to improve students' collaboration character as seen in the way students accepts task from the team, accept peers' opinions, and willingness to help others.
\end{abstract}

Keyword: thematic worksheet, local wosdom, cooperative character

\begin{abstract}
Abstrak
Penelitian ini bertujuan mengetahui keefektifan LKS tematik berbasis local wisdom terhadap karakter kerja sama siswa kelas 1 sekolah dasar. Penelitian ini merupakan penelitian quasi eksperimen dengan desain pretest posttest control group design. Populasi dalam penelitian ini adalah seluruh siswa kelas 1 sekolah dasar. Penelitian ini terdiri atas kelompok kontrol dan kelompok eksperimen. Kelompok kontrol adalah kelas 1B dengan jumlah 24 siswa dan kelompok eksperimen adalah siswa kelas 1A yang berjumlah 23 siswa. Teknik pengumpulan data yang digunakan adalah observasi dan wawancara. Untuk menguji keefektifan LKS tematik berbasis local wisdom terhadap karakter kerja sama siswa digunakan Independent Sample T-Test. Hasil penelitian menunjukkan bahwa penggunaan LKS tematik berbasis local wisdom efektif terhadap karakter kerja sama siswa kelas 1 . Hal ini didasarkan pada hasil uji hipotesis yang menunjukkan nilai sig 0,006 yang artinya nilai tersebut $<0,05$ maka $\mathrm{H}_{1}$ diterima. Selain itu, penggunaan LKS berbasis local wisdom di kelas eksperimen juga terbukti lebih dapat meningkatan karakter kerja sama siswa dalam beberapa aspek seperti anak menerima dengan baik tugas yang diberikan oleh kelompok, mau menerima pendapat dari teman lain ketika diskusi, dan anak bersedia membantu teman yang kesulitan.
\end{abstract}

Kata kunci: LKS tematik, local wisdom, karakter kerja sama

Histori artikel : disubmit pada 14 September 2018; direvisi pada 20 Oktober 2018; diterima pada 19 November 2018 


\section{A. PENDAHULUAN}

Pendidikan dan penguatan karakter saat ini menjadi suatu keharusan karena pendidikan sejatinya tidak hanya menjadikan peserta didik cerdas dalam hal kognitif, tetapi juga mempunyai budi pekerti dan kepribadian yang baik. Sejalan dengan pendapat Wibowo (2017) pendidikan karakter adalah pendidikan yang menanamkan dan mengembangkan karakter-karakter luhur kepada anak didik, sehingga mereka memiliki karakter luhur dan mampu menerapkan dalam kehidupannya, baik dalam kehidupan keluarga, anggota masyarakat, maupun warga negara.

Karakter individu pada diri seseorang dapat terbentuk akibat pengaruh dari keturunan maupun dari lingkungan, baik itu lingkungan keluarga, sekolah, maupun masyarakat. Penelitian sebelumnya yang dilakukan (Zuchdi, dkk., 2006) tentang studi pendidikan karakter melalui pengembangan keterampilan hidup dalam kurikulum persekolahan yang dilakukan pada semua jenjang pendidikan di Daerah Istimewa Yogyakarta diperoleh hasil antara lain (1) masih banyak sekolah yang belum mendukung pelaksanaan pendidikan karakter dengan optimal (2) strategi indoktrinasi dalam pendidikan karakter masih digunakan meskipun porsinya sedikit, (3) contoh keteladanan yang diberikan masih minim, dan (4) belum kondusifnya iklim pendidikan karakter.
Berdasarkan hasil penelitian tersebut pembinaan dan penanaman karakter sangat urgent dilakukan. Pendidikan karakter sebaiknya mulai diberikan sedini mungkin pada jenjang pendidikan dasar supaya anak lebih mudah menerima dan mengaplikasikannya. Hal ini juga sesuai dengan pendapat (Muslich, 2014) jika karakter tidak di tanamkan sejak dini maka akan sulit untuk membentuk dan merubah karakter yang sudah terbentuk sebelumnya.

Banyak nilai karakter yang dapat ditanamkan pada siswa, menurut Zubaedi (2015) ada sembilan pilar karakter dasar antara lain: 1) Cinta kepada Allah dan semesta berserta isinya; 2) tanggung jawab, disiplin, dan mandiri; 3) jujur; 4) hormat dan santun; 5) kasih sayang, peduli, dan kerja sama; 6) percaya diri, kreatif, kerja keras dan pantang menyerah; 7) keadilan dan kepemimpinan; 8) baik dan rendah hati; dan 9) toleransi, cinta damai, dan persatuan. Nilai-nilai yang telah disebutkan merupakan nilai yang dapat dikembangkan melalui pendidikan. Salah satunya nilai yang penting dikembangkan yaitu kerja sama. Karakter kerja sama penting dimiliki oleh setiap siswa, karena karakter tersebut mampu melatih siswa dalam memahami, merasakan, dan melaksanakan aktivitas kerja sama guna mencapai tujuan bersama (Rukiyati, dkk., 2014). Karakter kerja sama perlu ditanamkan sejak dini kepada anak karena karakter dapat menjadi bekal bagi kehidupan anak di masa yang akan datang. 
Seseorang dikatakan memiliki karakter kerja sama dapat dilihat dari tingkah laku maupun perbutannya. Indikator karakter kerja sama menurut Kemdiknas (2010) adalah 1) memberi pendapat dalam bekerja kelompok di kelas; 2) memberi dan mendengarkan pendapat dalam diskusi kelas; 3) ikut dalam kegiatan sosial dan budaya. Sedangkan indikator kerja sama menurut Pranowo (2013) adalah: 1) memanfaatkan waktu diskusi dengan baik; 2) menciptakan suasana akrab dalam kelompok; 3) mau mengalah dengan kelompok; 4) mendukung teman yang mengajukan pendapat baik; 5) tidak ingin menonjol dalam kelompok; 6) bisa menerima keputusan yang dilakukan kelompok; 7) memberi informasi yang diketahui untuk membantu penyelesaian tugas kelompok; 8) memotivasi / mendorong anggota yang kurang aktif dalam kelompok; dan 9) berpartisipasi aktif dalam diskusi.

Hasil penelitian terdahulu (Zuchdi, dkk, 2010) tentang pengembangan model pendidikan karakter terintegrasi dalam pembelajaran bidang studi di sekolah dasar menyimpulkan model pendidikan karakter yang efektif adalah model yang menggunakan pendekatan komprehensif. Pendekatan komprehensif yang dimaksud yaitu pembelajarannya tidak hanya melalui bidang studi tertentu, tetapi diintegrasikan ke dalam berbagai bidang studi menggunakan metode dan strategi yang bervariasi.

Berdasarkan hasil penelitian tersebut sudah seharusnya pendidikan karakter yang diterapkan di jenjang pendidikan sekolah dasar tidak diajarkan secara terpisah dalam mata pelajaran khusus tetapi melalui pembelajaran tematik dan dirancang khusus dengan metode atau strategi penanaman nilai yang bervariasi salah satunya melalui Lembar Kerja Siswa (LKS) tematik.

Agar pengintegrasian nilai dalam perangkat pembelajaran mudah diterima siswa, nilai yang bisa digunakan yaitu nilai-nilai yang bersumber dari kearifan lokal (local wisdom) masing-masing daerah. Kearifan lokal sendiri menurut Keraf (Wibowo \& Gunawan, 2015) diartikan sebagai hal-hal yang dikemas dalam bentuk pengetahuan, keyakinan, pemahaman, atau wawasan serta kebiasaan dan etika yang menuntut perilaku manusia dalam kehidupan bermasyarakat yang berkaitan dengan tata nilai kehidupan.

Hal ini sesuai dengan hasil penelitian Hajaroh, dkk. dalam (Rukiyati dan Purwastuti, 2016) yang menemukan salah satu pendekatan tematik integratif yang dapat diterapkan di sekolah yaitu dengan mengambil nilai-nilai budaya lokal sebagai bahan ajar untuk menanamkan karakter siswa. Selain itu menurut hasil penelitian yang dilakukan Wagiran (2012) salah satu upaya strategis dalam membangun karakter bangsa di era global yaitu dengan menggali nilai-nilai kearifan lokal.

Pendidikan berbasis kearifan lokal adalah pendidikan yang mengajarkan peserta didik untuk selalu lekat dengan situasi konkret yang mereka hadapi. Kearifan lokal merupakan modal pembentukan karakter luhur. Kearifan lokal yang seharusnya juga dilestarikan namun 
kini sering diabaikan dalam pembelajaran, hanya disampaikan secara sekilas kepada peserta didik, dan sebatas dipahami tetapi tidak untuk diterapkan dalam kehidupan sehari-hari.

Hal ini diperkuat dengan kondisi nyata yang ada di lapangan. Hasil observasi dan wawancara pada Bulan Desember 2017 di salah satu sekolah dasar Muhammadiyah di Yogyakarta informasi yang didapatkan sebagai berikut. Pertama karakter kerja sama siswa kelas I masih kurang, hal ini dilihat dari banyaknya peserta didik dalam proses pembelajaran yang sulit diajak bekerja sama dengan temannya. Selain itu ketika siswa diberikan tugas kelompok tugas tersebut tidak dikerjakan secara berdiskusi melainkan dikerjakan masing-masing individu.

Kedua, perangkat pembelajaran yang digunakan guru sudah mengikuti buku tematik, tetapi belum berbasis local wisdom. Guru juga masih kesulitan dalam memasukkan nilainilai kearifan lokal dalam perangkat pembelajaran. Guru hanya menggunakan buku tematik karena mengingat waktu yang tidak cukup untuk menjelaskan materi dalam satu pembelajaran sehingga perangkat pembelajaran seperti LKS hanya digunakan sebagai tugas untuk dikerjakan di rumah.

Penelitian sebelumnya telah dikembangkan LKS berbasis local wisdom untuk mengembangkan karakter siswa sekolah dasar khususnya kelas awal. Hasil penilaian beberapa ahli, LKS yang dikembangkan sudah layak dan baik, akan tetapi LKS belum pernah diuji coba langsung kepada siswa. Sehingga LKS yang telah dikembangkan perlu dilihat keefektifannya untuk menanamkan karakter kerjasama siswa sekolah dasar.

\section{B. METODE PENELITIAN}

Penelitian ini merupakan penelitian eksperimen semu (quasi experiment) (Sugiyono, 2015). Desain penelitian yang digunakan adalah pretest postest control group design menurut Creswell (2010) sebagai berikut.

Tabel 1. Desain Penelitian

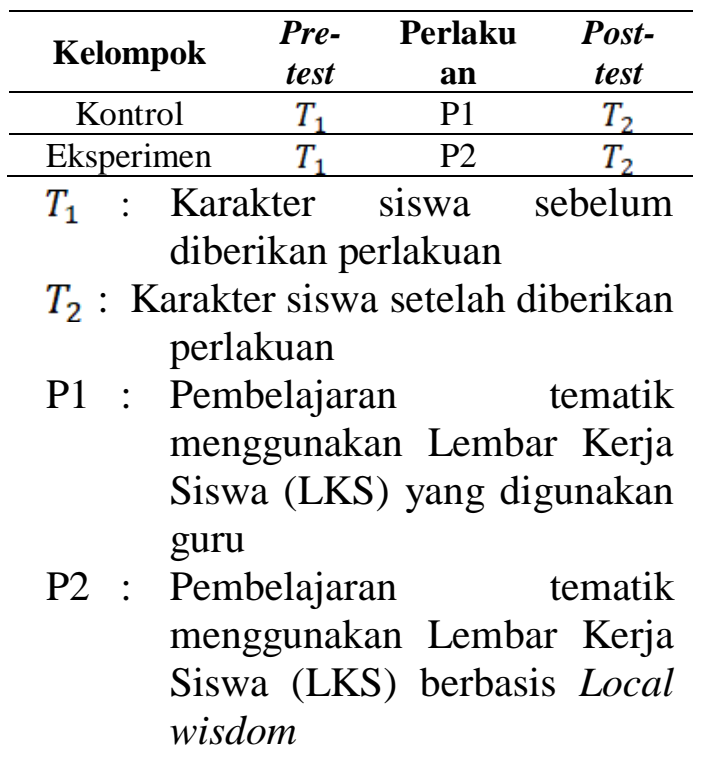

Penelitian ini dilakukan pada bulan April dan Mei 2018. Populasi dalam penelitian ini adalah siswa sekolah dasar kelas 1. Penelitian yang dilakukan terdiri atas kelompok kontrol dan kelompok eksperimen. Adapun yang dijadikan sebagai kelompok kontrol adalah kelas 1B dengan jumlah 24 siswa dan untuk kelompok eksperimen adalah siswa kelas 1A yang berjumlah 23 siswa.

Data yang dibutuhkan dalam penelitian ini yaitu data tentang karakter kerja sama siswa. Teknik pengumpulan data yang digunakan adalah observasi dan wawancara. 
Lembar observasi digunakan untuk mengetahui karakter kerja sama siswa selama proses pembelajaran ketika sebelum dan setelah perlakuan. Sedangkan wawancara digunakan untuk memperkuat informasi dari guru terkait karakter kerja sama siswa.

Data penelitian yang dianalisis adalah data penilaian karakter kerja sama sebelum dan setelah diberikan perlakuan. Data penilaian karakter yang dianalisis diperoleh dari masingmasing kelas yaitu kelas eksperimen dan kelas kontrol. Data penilaian karakter sebelum perlakuan diperuntukkan untuk mengetahui kondisi awal karakter dari kedua kelas tersebut. Selanjutnya, data penilaian karakter setelah diberikan perlakuan pada kelas eksperimen digunakan untuk mengetahui keefektifan LKS tematik berbasis local wisdom terhadap karakter kerja sama siswa.

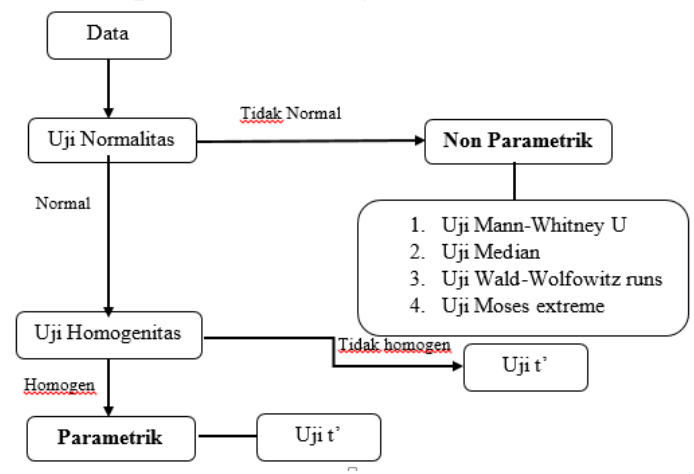

Gambar 1. Diagram Alur Statistik

Teknik analisis statistik yang digunakan merujuk pada pengujian hipotesis. Berdasarkan sampel yang digunakan yaitu kelas kontrol dan kelas eksperimen serta masing-masing sampel diberi perlakuan yang berbeda, maka bentuk hipotesis dalam penelitian ini adalah komparasi/komparatif pada dua sampel independen. Diagram alur teknik analisis statistik terhadap dua sampel independen disajikan sebagai berikut (Lestari, dkk., 2015).

Perhitungan analisis data dilakukan menggunakan aplikasi SPSS versi 21.0 dengan nilai signifikansi 0,05 dan taraf kepercayaan $95 \%$. Sebelum uji hipotesis menggunakan uji-t dilakukan uji prasyarat terlebih dahulu yaitu uji normalitas dan uji homogenitas. Uji normalitas dilakukan untuk mengetahui apakah data yang didapat berasal dari populasi yang berdistribusi normal atau tidak. Pada penelitian ini uji normalitas dilakukan dengan menggunakan uji KolmogorovSmirnov (Siregar, 2017, p. 153). Adapun kriteria pengujian, jika nilai uji Kolmogorov-Smirnov atau Sig. > 0,05 maka data berdistribusi normal, dan jika nilai Sig. $<0,05$ maka data tidak normal.

Uji homogenitas dilakukan untuk mengetahui apakah antara kelas eksperimen dan kelas kontrol memiliki varians yang homogen atau tidak. Uji homogen dilakukan secara univariat. Untuk menguji homogenitas variansi maka dilakukan dengan uji Levene's. dengan menggunakan $\alpha=0,05$ hipotesisnya $\mathrm{H}_{0}=$ populasi memiliki varians yang homogen, $\mathrm{H}_{1}=$ populasi memiliki varians yang tidak homogen. Kriteria pengujiannya adalah jika nilai signifikansi > 0,05 maka hipotesis nol diterima.

Untuk menguji hipotesis digunakan Uji $t$ ( $\left.t_{\text {test }}\right)$. Uji hipotesis yang digunakan dalam penelitian ini adalah independent sample t-test dengan menggunakan program SPSS versi 21.00. Uji ini dilakukan jika kedua data berdistribusi normal. Independent sample t-test digunakan 
untuk mengetahui ada atau tidaknya perbedaan rata-rata antar kedua kelompok sampel. Hipotesisnya sebagai berikut.

$\mathrm{H}_{0}=$ Tidak terdapat keefektifan antara kelas yang diberikan LKS berbasis local dengan kelas yang tidak diberikan perlakuan LKS berbasis local wisdom.

$$
\mathrm{H}_{1}=\text { Terdapat keefektifan antara }
$$
kelas yang diberikan LKS berbasis local wisdom dengan kelas yang tidak diberikan LKS berbasis local wisdom.

Pengambilan keputusan berdasarkan nilai signifikan yaitu jika nilai signifikansi $F_{\text {hitung }}>0,05$ maka $\mathrm{H}_{0}$ diterima dan jika nilai signifikansi $\mathrm{F}_{\text {hitung }}<0,05$ maka $\mathrm{H}_{0}$ ditolak.

Selain melakukan uji hipotesis dilakukan juga penilaian berdasarkan skor dalam tabel kategorisasi sikap yang dideskripsikan menggunakan komputer program excel dan SPSS versi 21.00. Distribusi frekuensi perilaku siswa dibuat dengan membuat kelas interval dengan skor yang telah ditentukan.

Untuk melihat tingkat kecenderungan skor dilakukan dengan menggunakan lima kategori skor menurut Sukarjo (Apriani dan Wangid, 2015) dengan rumus berikut.

Tabel 2.Konversi Skor Aktual Menjadi Skor Skala Lima Berdasarkan Simpangan Baku

\begin{tabular}{ccc}
\hline Interval Skor & Nilai & Kategori \\
\hline $\mathrm{X}>\mathrm{Mi}+1,8 \mathrm{Sbi}$ & $\mathrm{A}$ & Sangat Baik \\
\hline $\begin{array}{c}0,6 \mathrm{SBi}<\mathrm{X} \leq \mathrm{Mi} \\
+1,8 \mathrm{SBi}\end{array}$ & $\mathrm{B}$ & Baik \\
\hline $\begin{array}{c}0,6 \mathrm{SBi}<\mathrm{X} \leq \mathrm{Mi} \\
+0,6 \mathrm{SBi}\end{array}$ & $\mathrm{C}$ & Cukup Baik \\
\hline $\begin{array}{c}\mathrm{Mi}-1,8 \mathrm{SBi}<\mathrm{X} \leq \mathrm{Mi} \\
-0,6 \mathrm{SBi}\end{array}$ & $\mathrm{D}$ & Kurang Baik \\
\hline $\mathrm{X} \leq \mathrm{Mi}-1,8 \mathrm{SBi}$ & $\mathrm{E}$ & $\begin{array}{c}\text { Sangat } \\
\text { Kurang Baik }\end{array}$ \\
\hline
\end{tabular}

Keterangan:

$\mathrm{X}$ : skor aktual (empiris)
Mi : mean ideal, dihitung dengan menggunakan rumus: $\mathrm{Mi}=1 / 2$ (skor maks ideal + skor minimal ideal)

SBi : simpangan baku ideal, ditentukan dengan rumus: $\mathrm{SBi}=$ 1/6 (skor maks ideal - skor minimal ideal)

\section{HASIL DAN PEMBAHASAN}

Data pre-test dan post-test kelas eksperimen dan kelas kontrol diperoleh melalui pengamatan menggunakan lembar observasi. Penelitian dibantu oleh lima orang pengamat dan setiap pengamat mengisi lembar pengamatan yang telah disediakan sesuai dengan kriteria setiap indikator dari karakter kerja sama. Kemudian semua hasil pengamatan dihitung dan diambil ratarata selama satu minggu.

Pre-test dilakukan dengan mengamati karakter siswa dalam pembelajaran sebelum diberikan perlakuan, baik itu di kelas eksperimen maupun di kelas kontrol. Pembelajaran di kelas eksperimen menggunakan LKS tematik berbasis local wisdom sedangkan di kelas kontrol menggunakan LKS yang digunakan guru. Setelah kedua kelas diberikan perlakuan yang berbeda, selanjutnya dilakukan pengamatan secara berkala. Pengamatan dilakukan untuk melihat keefektifan LKS tematik berbasis local wisdom terhadap karakter kerja sama siswa.

Hasil penilaian karakter kerja sama didasarkan pada pengamatan di kelas ketika pembelajaran berlangsung. Cara untuk mengukurnya yaitu dengan menghitung skor keseluruhan yang diperoleh siswa 
kemudian hasil penilaian yang didapat dianalisis berdasarkan tabel kategori karakter siswa.

Tabel 3. Kategori Karakter Kerja Sama Siswa

\begin{tabular}{ccl}
\hline Interval Skor & Nilai & \multicolumn{1}{c}{ Kategori } \\
\hline$X>34$ & A & Sangat Baik \\
\hline $28<X \leq 34$ & B & Baik \\
\hline $22<X \leq 28$ & C & Cukup Baik \\
\hline $16<X \leq 22$ & D & Kurang Baik \\
\hline$X \leq 16$ & E & $\begin{array}{l}\text { Sangat Kurang } \\
\text { Baik }\end{array}$ \\
\hline
\end{tabular}

Adapun distribusi frekuensi dan persentase karakter kerja sama pre-test dan post-test untuk kelas kontrol dan eksperimen disajikan pada tabel berikut.

Tabel 4. Distribusi Frekuensi dan Persentase Karakter Kerja Sama Pre-Test dan Post-Test

\begin{tabular}{lcccccccc}
\hline Kate & \multicolumn{3}{c}{ Kelas Kontrol } & \multicolumn{3}{c}{ Kelas Eksperimen } \\
\cline { 2 - 8 } & Pre-test & $\begin{array}{c}\text { Post- } \\
\text { test }\end{array}$ & \multicolumn{2}{c}{ Pre-test } & \multicolumn{2}{c}{$\begin{array}{c}\text { Post- } \\
\text { test }\end{array}$} \\
\cline { 2 - 9 } $\begin{array}{l}\text { Sang } \\
\text { at }\end{array}$ & 0 & 0 & 0 & 0 & 0 & 0 & 5 & 21,7 \\
Baik & & & & & & & & \\
\hline Baik & 3 & 12,5 & 4 & 16,6 & 5 & 21,7 & 7 & 30,4 \\
\hline $\begin{array}{l}\text { Cuku } \\
\text { p }\end{array}$ & 16 & 66,7 & 1 & 66,7 & 1 & 52,2 & 9 & 39,2 \\
Baik & & & 6 & & 2 & & & \\
\hline $\begin{array}{l}\text { Kura } \\
\text { ng }\end{array}$ & 5 & 20,8 & 4 & 16,6 & 6 & 26,1 & 2 & 8,7 \\
Baik & & & & & & & & \\
\hline $\begin{array}{l}\text { Sang } \\
\text { at }\end{array}$ & 0 & 0 & 0 & 0 & 0 & 0 & 0 & 0 \\
$\begin{array}{l}\text { Kura } \\
\text { ng }\end{array}$ & & & & & & & & \\
Baik & & & & & & & & \\
\hline
\end{tabular}

Berdasarkan hasil dari data yang diperoleh hasil pre-test dan post-test karakter kerja sama di kelas kontrol tidak jauh berbeda. Hal ini ditunjukkan dari hasil yang diperoleh yaitu pre-test untuk kategori sangat baik masih tetap sama 0\% dengan hasil post-testnya. Untuk karakter kerja sama dengan kategori baik hanya meningkat sedikit yaitu dari 3 siswa menjadi 4 siswa. Sedangkan untuk karakter kerja sama siswa dengan kategori cukup baik masih tetap sama antara hasil pre-test dan post-testnya yaitu sebanyak 16 siswa. Dan untuk kategori kurang baik mengalami peningkatan sedikit antara hasil pretest dan post-testnya yaitu dari 5 siswa yang karakternya kurang baik menjadi 4 siswa, serta untuk karakter kerja sama kategori sangat kurang baik masih sama yaitu $0 \%$.

Hasil yang didapatkan pada kelas eksperimen berdasarkan data pre-test dan post-testnya diperoleh bahwa karakter kerja sama antara pretest dan post-test berbeda, yaitu hasil post-test meningkat. Hal ini ditunjukkan dari hasil yang diperoleh yaitu karakter kerja sama dengan kategori sangat baik yang semula 0 siswa menjadi 5 siswa. Karakter kerja sama dengan kategori baik meningkat dari 5 siswa pada saat pre-test menjadi 7 siswa saat post-test. Sedangkan untuk karakter kerja sama dengan kategori cukup baik dari hasil pre-test diperoleh 12 siswa sedangkan post-test menjadi 9 siswa. Sedangkan untuk karakter kerja sama dengan kategori kurang baik mengalami penurunan dari 6 siswa menjadi 2 siswa, serta untuk karakter kerja sama dengan kategori sangat kurang baik tetap sama yaitu $0 \%$.

Selanjutnya dilakukan uji prasyarat yaitu uji normalitas dan homogenitas. Uji normalitas dilakukan pada kedua kelompok dengan tujuan untuk mengetahui data sampel berasal dari populasi yang berdistribusi normal atau tidak. Uji normalitas menggunakan rumus KolmogorovSmirnov dalam perhitungan menggunakan program SPSS 21.00. 
Untuk mengetahui normal tidaknya data apabila jika sig > 0,05 maka normal dan jika sig $<0,05$ dapat dikatakan tidak normal. Hasil uji normalitas univariat disajikan pada tabel sebagai berikut.

Tabel 5.Hasil Uji Normalitas

\begin{tabular}{lcc}
\hline \multicolumn{1}{c}{ Kelas } & Sig. & Keterangan \\
\hline Kontrol & 0,764 & Normal \\
\hline Eksperimen & 0,369 & Normal \\
\hline
\end{tabular}

Berdasarkan Tabel 5, terlihat bahwa nilai sig kelas kontrol maupun kelas eksperimen > 0,05 yaitu untuk kelas kontrol memiliki nilai sig. 0,764 yang artinya lebih besar dari 0,05 dan untuk kelas eksperimen memiliki nilai sig. 0,369 yang artinya juga lebih besar dari 0,05. Maka dengan melihat hasil tersebut dapat disimpulkan bahwa kelompok data tersebut berdistribusi normal.

Setelah diketahui tingkat kenormalan data, selanjutnya dilakukan uji homogenitas. Uji homogenitas dilakukan untuk mengetahui tingkat kesamaan varians antara dua kelompok yaitu kelompok eksperimen dan kelompok kontrol. Untuk menerima atau menolak hipotesis dengan membandingkan nilai sig pada levene's statistic dengan 0,05 (sig > 0,05). Berdasarkan hasil perhitungan uji homogenitas diketahui Fhitung pre-test sebesar 0,418 dengan nilai signifikan 0,521. Dari hasil tersebut, nilai signifikansi lebih besar dari 0,05 maka disimpulkan data dalam penelitian ini memiliki varians yang homogen.

Uji hipotesis yang digunakan dalam penelitian ini adalah independent sample t-test dengan menggunakan program SPSS versi
21.00. Independent sample t-test digunakan untuk mengetahui ada atau tidaknya perbedaan rata-rata antar kedua kelompok sampel. Data yang dimasukkan dalam uji hipotesis diambil dari data post-test kelas kontrol dan kelas eksperimen setelah diberikan perlakuan yang berbeda. Berdasarkan hasil uji hipotesis menggunakan uji independent sample t-test menghasilkan $F_{\text {hitung }}$ sebesar 8,428 dengan nilai signifikansi 0,006 . Dari hasil tersebut nilai uji hipotesis lebih kecil dari 0,05. Maka dapat disimpulkan bahwa hipotesis nol $\left(\mathrm{H}_{0}\right)$ ditolak atau $\left(\mathrm{H}_{1}\right)$ diterima. Hal ini membuktikan bahwa LKS tematik berbasis local wisdom efektif terhadap karakter kerja sama siswa.

Hasil karakter kerja sama di kelas kontrol dan kelas eksperimen juga dapat dibuktikan dengan melihat perbandingan setiap indikator kerja sama sebelum dan sesudah perlakuan. Ada sepuluh indikator kerja sama dalam penelitian ini yaitu (1) Berpartisipasi aktif dalam diskusi kelompok, (2) Memanfaatkan waktu berdiskusi dalam kelompok dengan baik, (3) Menerima pendapat dari teman dalam berdiskusi, Membantu teman kelompok yang merasa kesulitan, (5) Menerima keputusan yang dilakukan kelompok, (6) Menciptakan suasana yang akrab dalam diskusi kelompok, Mendukung teman yang memberikan pendapat baik, (8) Memberi motivasi pada anggota kelompok yang kurang aktif, (9) Bertanggungjawab dengan tugas yang telah diberikan dalam kelompok, (10) Menyampaikan pendapat atau ide kepada anggota 
kelompok lain dengan bahasa yang santun.

Pada kelas kontrol diterapkan LKS yang biasa digunakan oleh guru, hasilnya ada lima indikator kerjasama yang tidak mengalami peningkatan dari sebelum dan setelah perlakuan yaitu kemauan siswa memanfaatkan waktu berdiskusi dalam kelompok dengan baik, kemauan siswa menerima keputusan yang dilakukan kelompok, kemampuan siswa menciptakan suasana yang akrab dalam diskusi kelompok, kemauan siswa memberi motivasi pada anggota kelompok yang kurang aktif, dan kemauan siswa menyampaikan pendapat atau ide kepada anggota kelompok lain dengan bahasa yang santun. Sedangkan kelima indikator lain mengalami peningkatan namun hanya sedikit.

Sedangkan di kelas eksperimen yang menerapkan LKS berbasis local wisdom, hasilnya semua indikator kerjasama siswa mengalami peningkatan dengan baik. Peningkatan kerjasama siswa yang termasuk tinggi yaitu pada enam indikator yaitu Memanfaatkan waktu berdiskusi dalam kelompok dengan baik, Menerima pendapat dari teman dalam berdiskusi, Membantu teman kelompok yang merasa kesulitan, Menerima keputusan yang dilakukan kelompok, Mendukung teman yang memberikan pendapat baik, Memberi motivasi pada anggota kelompok yang kurang aktif, dan Bertanggungjawab dengan tugas yang telah diberikan dalam kelompok.

Temuan yang telah diperoleh menunjukkan bahwa LKS tematik berbasis local wisdom memberikan pengaruh positif atau lebih baik dalam meningkatkan karakter kerja sama siswa. Hal ini diperkuat sesuai hasil penelitian Eka Pradita dan Nur Wangid (2017) yang menunjukkan penerapan LKPD tematik-integratif berpengaruh positif terhadap karakter peserta didik sekolah dasar. LKPD tematik integratif membuat siswa lebih tertarik belajar karena kegiatan pembelajaran dalam LKPD dirancang dengan bertitik tolak pada kondisi nyata sesuai dunia peserta didik. Selain itu melalui LKPD peserta didik juga diberi kesempatan untuk membangun pengetahuannya sendiri secara langsung melalui kegiatan eksperimen, tanya jawab, maupun diskusi kelompok sehingga juga berpengaruh terhadap karakternya.

LKS tematik dalam penelitian ini adalah LKS yang diintegrasikan dengan nilai-nilai local wisdom yang terdapat di wilayah Yogyakarta. Adapun jenis local wisdom yang ada di LKS meliputi lagu daerah, permainan tradisional, tarian daerah, alat musik tradisional serta kesenian daerah Yogyakarta. Salah satu contoh jenis kearifan lokal yang terdapat dalam LKS ini adalah permainan "Cublak-Cublak Suweng” yang diringi dengan lagu dengan lirik sebagai berikut.

\section{cublak-cublak suweng suwenge ting gelenter mambu ketundung gudel pak empong lera-lere sopo ngguyu ndelikkake sir sir pong dhele gosong sir sir pong dhele gosong}

Permainan cublak cublak suweng merupakan permainan yang 
harus dilakukan secara kelompok. Permainan ini diawali dengan menentukan satu anak dalam kelompok biasanya dengan cara pingsut yang akan bertugas untuk menemukan "suweng" atau anting. Pada umumnya anting yang dimaksud diganti dengan benda lain seperti batu atau kerikil. Anak yang bertugas mencari kerikil harus berbaring telungkup, sedangkan anak lain yang tidak bertugas duduk melingkar mengelilingi anak yang telungkup dengan menyanyikan lagu cublak cublak suweng sambil memutar kerikil dari telapak tangan anak satu ke anak yang lain.

Setelah lagu selesai dinyanyikan, anak yang telungkup bangun sedangkan anak-anak yang lain harus berpura-pura memegang kerikil menggunakan tangan kanan dan kiri dengan rapat. Tugas anak yang telungkup yaitu menemukan kerikil yang disembunyikan anak-anak lain. Permainan akan terus dilanjutkan jika anak yang telungkup tidak bisa menunjuk anak dengan benar.

Hal ini diperkuat dengan hasil penelitian yang dilakukan Rukiyati dan Purwastuti (2016, p.136) yang mengkaji tentang model pendidikan karakter berbasis kearifan lokal pada sekolah dasar di Yogyakarta. Hasil penelitian menunjukkan permainan cublak-cublak suweng dapat melatih anak untuk bekerja sama, jujur, tidak curang, bertanggung jawab, dan berani. Nilai kerja sama dalam permainan cublak cublak suweng ditanamkan kepada anak-anak dengan cara anak belajar memerankan perannya masing-masing dengan baik agar tidak ada yang ketahuan siapa yang memegang suweng/ anting.

Karakter yang dibangun dengan LKS tematik berbasis local wisdom menjadi lebih mudah dipahami karena kegiatan pembelajaran yang dilakukan merupakan suatu hal yang dekat dengan kehidupan siswa. Karakter sendiri merupakan suatu nilai yang diwujudkan ke dalam sebuah perilaku yang terbentuk karena suatu kebiasaan dan karakter juga terbentuk akibat pengaruh dari lingkungan dimana individu berada. Hal ini sesuai dengan pendapat Samani dan Hariyanto (2017) yang menyatakan karakter seseorang diwujudkan dalam perilaku yang terbentuk karena suatu kebiasaan dimana orang tersebut berada.

Penerapan LKS tematik berbasis local wisdom ini tidak hanya efektif terhadap karakter kerja sama siswa, namun juga mempengaruhi pengetahuan siswa tentang kearifan lokal yang ada di daerahnya. Hal ini dapat dibuktikan ketika siswa diminta untuk menyebutkan jenis permainan tradisional, lagu, atau tarian tradisional, semula siswa hanya bisa menyebutkan dua sampai dengan tiga jenis saja. Namun setelah dilakukan pembelajaran menggunakan LKS berbasis local wisdom, siswa menjadi lebih paham.

Pendidikan karakter yang diterapkan di sekolah memang seharusnya tidak diajarkan dalam mata pelajaran khusus. Pembentukan karakter anak dapat dilatih dan ditanamkan dengan mengintegrasikan dalam pembelajaran dan kegiatan keseharian yang ada di sekolah. Semua nilai karakter yang ada tidak dapat berdiri sendiri. Hal ini sesuai 
dengan pendapat Anita Lie (Judiani, 2010) yang mengatakan bahwa karakter bukan suatu mata pelajaran yang berdiri sendiri, tetapi harus diintegrasikan dalam pembelajaran dan keseharian anak.

\section{SIMPULAN}

Berdasarkan hasil penelitian yang diperoleh penerapan Lembar Kerja Siswa tematik berbasis local wisdom berpengaruh signifikan terhadap kakarter kerjasama siswa. Rata-rata peningkatan karakter kerja sama yang mengikuti pembelajaran menggunakan LKS tematik berbasis local wisdom juga lebih besar dibandingkan kelas yang tidak menggunakan LKS tematik berbasis local wisdom.

$\begin{array}{lrrr}\text { Saran } & \text { yang } & \text { dapat } & \text { diberikan } \\ \text { kepada } & \text { guru } & \text { agar } & \text { bisa } \\ \text { mengintegrasikan } & & \text { perangkat }\end{array}$
pembelajaran lainnya seperti silabus, RPP, bahan ajar maupun LKS dengan nilai-nilai yang berumber dari kearifan lokal daerah masing-masing. Harapannya pembelajaran menjadi lebih dekat dengan situasi nyata dan nilai kearifan lokal juga dapat terus dilestarikan.

\section{DAFTAR RUJUKAN}

Apriani, A. \& Muhammad N. W. (2015). Pengaruh SSP Tematik Integratif terhadap Karakter Disiplin dan Tanggung Jawab Siswa Kelas III SD. Jurnal Prima Edukasia, 3(1), 12-25.

Creswell, J. W. (2010). Research Design: Pendekatan Kualitatif, Kuantitatif, dan Mixed. Yogyakarta: Pustaka Pelajar.
Eka, P. Nurjannah \& Muhammad N. W. (2017). Pengembangan LKPD Tematik-Integratif Berbasis Karakter Pada Peserta Didik Sekolah Dasar. Jurnal Pendidikan Karakter. 7(1).

Judiani, S. (2010). Implementasi Pendidikan Karakter di Sekolah Dasar Melalui Penguatan Pelaksanaan Kurikulum. Jurnal Pendidikan dan Kebudayaan Setditjen Manajemen PendidiSkarin $J$ Dudaisaanri dan Menengah, Kemendiknas. 16(3), 281-284.

Kemdiknas. (2010). Rencana Strategis Kementrian Pendidikan Nasional 2010-2014, Jakarta: Kemdiknas.

Lestari, K. E. \& Mokhammad R. Y. (2015). Penelitian Pendidikan Matematika, Bandung: Refika Aditama.

Muslich, M. (2014). Pendidikan Karakter Menjawab Tantangan Krisis Multidimensional, Jakarta: Bumi Aksara.

Pranowo, D. J. (2013). Implementasi Pendidikan Karakter Kepedulian dan Kerja Sama pada Mata Kuliah Keterampilan Berbicara Bahasa Prancis dengan Metode Bermain Peran. Jurnal Pendidikan Karakter. 3(2). 225.

Rukiyati \& L. Andriani P. (2016). Model Pendidikan Karakter Berbasis Kearifan Lokal Pada Sekolah Dasar Di Bantul Yogyakarta. Jurnal Pendidikan Karakter. 7(1).

Rukiyati, N. S. \& Priyoyuwono. (2014). Penanaman Nilai Tanggung Jawab dan Kerja Sama Terintegrasi dalam Perkuliahan Ilmu Pendidikan. 
Jurnal Pendidikan Karakter. 4(2).

Samani, M. \& Hariyanto. (2017). Konsep dan Model Pendidikan Karakter, Bandung: Remaja Rosdakarya.

Sugiyono. (2015). Metode Penelitian dan Pengembangan, Bandung: Alfabeta.

Warigan. (2012). Pengembangan Karakter Berbasis Kearifan Lokal Hamemayu Hayuning Bawana. Jurnal Pendidikan Karakter, 2(3).

Wibowo, A. \& Gunawan. (2015). Pendidikan Karakter Berbasis Kearifan Lokal di Sekolah, Yogyakarta: Pustaka Pelajar.

Wibowo, A. (2017). Pendidikan Karakter Usia Dini Strategi Membangun Karakter di Usia Ema, Yogyakarta: Pustaka Pelajar.

Zubaedi. (2015). Desain Pendidikan Karakter Konsep dan Aplikasinya dalam Lembaga Pendidikan, Jakarta: Prenadamedia Group.

Zuchdi, D. (2006). Pendidikan Karakter Melalui Pengembangan Keterampilan Hidup dalam Kurikulum Persekolahan. Laporan Penelitian Hibah Pasca 20052006. Yogyakarta: Lembaga Penelitian UNY.

Zuchdi, D. (2010). Pengembangan Model Pendidikan Karakter Terintegrasi dalam Pembelajaran Bidang Studi di Sekolah Dasar. Cakrawala Pendidikan Jurnal Pengembangan Model Pendidikan Karakter Terintegrasi. 1(3). 1-15. 